Петрова, Тетяна. «Жанрові типи рецензій на термінологічні словники». Лінгвостилістичні студї, вип. 11, 2019, c. $124-35$.

Petrova, Tetiana. "Terminology Dictionary Reviews: Genre Typology”. Linguostylistic Studies, iss. 11, 2019, pp. 124-35.

УДК 82-95:811.161.2'374.26

https://doi.org/10.29038/2413-0923-2019-11-124-135

\title{
ЖАНРОВІ ТИПИ РЕЦЕНЗІЙ НА ТЕРМІНОЛОГІЧНІ СЛОВНИКИ
}

\author{
Тетяна Петрова \\ Харківський національний аграрний університет імені В. В. Докучаєва, \\ Харків, Україна
}

У статті запропоновано багатоаспектну жанрову типологію рецензій на термінологічні словники. Детально розглянуто два типи рецензій за ознаками 'кількість авторів' (одноосібні й колективні) і 'тип журналу, у якому вміщено рецензію' (у наукових академічних журналах і в журналах неакадемічного рівня). 3’ясовано, що особливістю аналізованих типів рецензій $є$ наявність численних їхніх різнорідних підтипів. Установлено, що існування значної кількості жанрових різновидів та сучасних джерел репрезентування рецензії засвідчує її запотребованість і важливу роль як інструмента підвищення якості національної термінографічної продукції.

Ключові слова: рецензія на термінологічний словник, жанрова типологія рецензій, тип рецензії, термінологічний словник, академічний журнал.

\section{TERMINOLOGY DICTIONARY REVIEWS: GENRE TYPOLOGY Tetiana Petrova}

Kharkiv National Agrarian University named after V. V. Dokuchaiev, Kharkiv, Ukraine

Genre typology of special dictionary reviews is a difficult task that implies detecting the specific features of every review genre to define its typological genre characteristics. The review of a terminology dictionary is 1) a kind of an expert opinion on the review of terminography edition, its estimation; 2) the representation of a critical sub-discourse, the basic genre of the terminography criticism.

Analysis of the structure and the content of special dictionaries reviews, their multidimensional genre typology draws on the following characteristics (parameters): 1) the number of authors; 2) a type of the journal in which the review is published; 3) the amount of information in the review; 4) the number of dictionaries considered in the review; 5) the type of special dictionaries analyzed in the review; 6) the presence / absence of scientific discussion, i.e. the presence / absence of responses to the review; 7) the style of text presentation in the review; 8) the time to react to the dictionary publication.

According to the characteristic 'the number of authors' there are the following types and subtypes of the reviews: 1) individual (according to the specialty of the experts - branch experts' reviews and linguists' / terminographers' reviews); 2) collective (according to the specialty of the experts - the reviews of the representatives of the same specialty and the reviews of the representatives of different specialties). The selected types of the reviews by the specialization and the number of authors vary in volume, depth of the analysis, and argumentation accuracy regarding advantages or disadvantages of the dictionary.

(C) Петрова Т., Східноєвропейський національний університет імені Лесі Українки, 2019.

Це стаття відкритого доступу на умовах CC BY-NC 4.0 
According to the characteristic 'a type of the journal in which the review was published' we distinguish (1) the reviews in scientific academic journals (by the type of a journal linguistic and branch), (2) the reviews in non-academic (popular) journals (by the kind of media - electronic and paper). The existence of a large number of genre varieties and modern opportunities for review presentation attests a growing demand for the genre and its significance in improving the quality of national terminographic products.

Key words: terminology dictionary review, genre typology of reviews, review type, terminology dictionary, academic journal.

Вступ. Типологізування жанрових різновидів рецензій на спеціальні словники - складне питання, що потребує врахування специфіки проведення рецензування праць такого типу, їхніх диференційних характеристик, а також жанрових особливостей рецензій. Рецензування спеціального словника - багатокрокова процедура критичного аналізу видання з метою дати йому оцінку за різними критеріями й визначити його якість. Рецензія на термінологічний словник - 1) своєрідний експертний висновок розгляду термінографічного видання, його оцінка; 2) репрезентант критичного субдискурсу, базовий жанр термінографічної критики, «вторинний текст, у якому виклад інформації грунтується на результатах оброблення та аналізування первинного тексту термінографічного видання. Композиційні елементи рецензії підпорядковані конкретній меті: комплексно, усебічно оцінити й схарактеризувати рецензований термінологічний словник» (Петрова, «Українська» 211). Рецензія хоч і належить до системи малих жанрів, однак вона покликана порушувати й розв'язувати 'великі' проблеми термінологічної лексикографії - створення нового типу термінологічного словника, розроблення універсальних лексикографічних параметрів, вироблення принципів добирання терміноодиниць до його реєстру тощо.

Вивченню різних аспектів наукової рецензії присвячені праці українських (О. Гуманенко, І. Левчук, Н. Мех, Н. Яценко та ін.) і зарубіжних науковці (H. Bergenholtz i R. H. Gouws, Е. Лассан, Б. Степанов, М. Чернишова, В. Щербін та ін.). Жанрове типологізування різновидів постпублікаційних рецензій на термінологічні словники до цього часу не здійснено, що визначає актуальність цього дослідження.

Мета статті - виділити жанрові типи постпублікаційних рецензій на термінологічні словники, розробити багатоаспектну жанрову типологію рецензій на спеціальні видання; завдання - схарактеризувати особливості жанрових типів і підтипів рецензій на фахові словники.

Матеріал і методи дослідження. Джерельною базою слугують 50 рецензій на термінологічні словники, що опубліковані в українській науковій періодиці й становлять корпус текстів критичного субдискурсу.

У статті застосовано такі методи: описовий (для узагальнення й типологізування жанрових різновидів рецензій на термінологічні словники), порівняльний (для встановлення відмінностей, глибини аналізу словників утекстах рецензій), кількісного аналізу (для визначення 
кількості авторів рецензії), лексикографічного аналізу (для вивчення характеристики лексикографічних параметрів словника в тексті рецензіі).

Результати дослідження та дискусія. Різноманіття типів рецензії відстежуємо в журналістиці й літературознавстві, напр.: анотація, коротка рецензія (відгук), реферативна рецензія, звичайна газетна (журнальна) рецензія, проблемна рецензія, рецензія-есе, рецензія-діалог, рецензіяфейлетон, рецензія-памфлет, рецензія-жарт, рецензія-лист, авторецензія, рецензентська репліка (Літературознавчий 242). Рецензія як жанр української термінографічної критики теж характеризується неоднорідністю типів.

У науковій літературі цінними $є$ публікації зарубіжних лінгвістів стосовно типів рецензій на загальномовні лексикографічні видання. Наприклад, білоруський дослідник В. Щербін у статті про внесок 0. Трубачова в розвиток наукової лексикографічної критики репрезентує всеохопну характеристику різних типів рецензій (загалом 76 найменувань) цього науковця за такими ознаками: 1) кількість розглядуваних у ній словників - (а) рецензї-огляди, (б) монорецензії; 2) тип розглядуваних у них словників; 3) мовна характеристика розглядуваних словників; 4) участь або неучасть автора рецензї у створенні рецензованих словників - (а) власне рецензї̈, (б) авторецензії (Щербин 6).

Данські науковці Х. Бергенхольц і Р. Х. Гууз виділяють шість типів рецензій на неспеціальні словники: 1) коротка характеристика без критичної оцінки; 2) огляд публікації загалом; 3) оглядова стаття, що пропонує багатоаспектну та науково обгрунтовану характеристику; 4) відповідь автора металексикографічної роботи або словника на огляд чи оглядову статтю; 5) експертні оцінки, наприклад, металексикографічні публікації та тези конференцій; 6) оцінка словника або аспектів одного чи декількох словників як частини більшої металексикографічної публікації (переклад автора. - Т. П.) (Bergenholtz, and Gouws 62).

Авторка цієї статті сумнівається в потребі виділення в наведеній вище класифікації четвертого типу рецензії, зокрема в запропонованому формулюванні - «відповідь автора металексикографічної роботи або словника на огляд чи оглядову статтю», оскільки відповідь на критику - це не рецензія, а публікація дискусійного характеру, полеміка. У цьому разі, як видається, більш коректно методологічно виокремлювати два типи рецензій: рецензії, що отримали відповідь автора (авторів) словника, i рецензії, що не отримали відповіді автора (авторів) словника.

Ураховуючи розроблені українськими та зарубіжними науковцями типології рецензій на лексикографічні праці, а також власні спостереження й напрацювання, спробуймо виділити й докладно схарактеризувати жанрові типи рецензій (можливі їхні підтипи) на термінологічні словники, запропонувавши їхню універсальну жанрову типологію. 
Так, на підставі проведеного аналізу композиції й змісту рецензій на спеціальні словники здійснено їхню багатоаспектну жанрову типологію за такими ознаками (параметрами):

1) кількість авторів;

2) тип журналу, уякому вміщено рецензію;

3) обсяг ї̈ інформацї;

4) кількість розглядуваних у ній словників;

5) тип аналізованих спеціальних словників;

6) наявність / відсутність наукової дискусії, тобто наявність / відсутність відповіді на рецензію;

7) стиль викладу тексту в рецензії;

8) час реагування на вихід у світ словника.

Обсяг цієї статті не дає змоги розглянути всі типи критичних публікацій за виділеними ознаками, тому в цій розвідці проаналізуємо типи рецензій за першими двома ознаками - 'кількість авторів' і 'тип журналу, де вміщено рещензію'.

Зауважмо, що в науковій літературі існують праці, присвячені окремим з наведеної вище типології жанровим типам рецензій на термінологічні словники за ознаками 'обсяг інформації' (Петрова, «Рецензія... як жанр») та 'наявність / відсутність наукової дискусії, тобто наявність / відсутність відповіді на рецензію' (Петрова, «Рецензія... експертиза»).

1. Рецензії за ознакою 'кількість авторів рецензії. «Особистість автора тексту, його роль у суспільстві постають значущими у вияві перцептивної функції спілкування (функція сприйняття). Розглядаючи текстову інформацію, адресант сприймає почуте / побачене через образ самого автора, його ментально-психологічні параметри. Перцептивна функція в сучасній психокомунікативістиці виявлювана й у здатності адресанта сприймати світ очима інших, усвідомлювати його так, як вони, простежувати перебіг подій і фактів з позицій адресатів» (Загнітко 262). Так, рецензент повідомляє читачам, тобто адресатам, результати аналізування словника, спираючись на власні судження й знання. У цій статті використовуємо терміноодиниці рецензент, критик, а також експерт на позначення автора критичної публікації. Рецензія, як видається, це своєрідний експертний висновок якості словника як спеціального видання, відповідно, зазначене й дає право називати автора рецензії експертом.

За ознакою 'кількість авторів рецензіі' існують одноосібні та колективні типи рецензій.

1.1. Одноосібна рецензія - оцінна публікація одного експерта, присвячена термінологічному словнику (Космеда; Кочан; Потоцький). Із-поміж одноосібних рецензій за фахом експертів виділяємо рецензї галузевих фахівців і рецензії мовознавців / термінографів. 
Головне завдання критика термінографічного видання - виявити в рецензованому словникові те, чого не помітили інші. Для цього експертові потрібно володіти спеціальними знаннями словникарської діяльності, розуміти специфіку системної організації певної термінології, а також теоретичне підгрунтя галузі, щоб репрезентувати ії в словнику. Головне, рецензент повинен бути авторитетним науковцем, з високим рівнем критичного мислення.

Рецензентами, як виявляється, можуть бути: (1) галузеві фахівці / нетермінографи, (2) мовознавці / термінографи, (3) мовознавці / термінографи й галузеві фахівці. Яскравими прикладами означених типів рецензій за фахом експертів $\epsilon$ три рецензії на «Словник української біологічної термінології» (Словник). Відстежмо особливості кожного типу рецензії за названою ознакою.

Рецензія галузевих фахівців - це зазвичай невелика за обсягом публікація (1-2 сторінки), у якій рецензент-фахівець характеризує насамперед сучасний стан розвитку описуваної науки чи галузі, пояснює актуальність укладання словника. Так, М. Потоцький визначає вихід словника як незвичайну подію, порівн.: «<...> сталася велика неординарна подія - побачив світ академічний "Словник української біологічної термінології”, створений колективом термінологів Інституту української мови та Комітету наукової термінології НАН України» (181).

Щодо структури й принципів лексикографічного репрезентування термінів у виданні рецензент-фахівець коротко подає загальну оцінку (1-2 абзаци), переказуючи інформацію про нього з анотації чи передмови, напр.: «<...> це солідний за обсягом (46,5 ум. друк. ар.) і змістом (близько 80 тис. термінів і термінів-словосполучень) - нормативний тримовний дефінітивно-перекладний словник, у якому зафіксовано лише усталені в мові лексичні одиниці, граматичні форми, наголоси, що відповідають вимогам сучасного правопису, напр.: амфіка́ріон, -а (рос. амфика́рион, англ. amphikarion) - ядро дроблення, що виникає в процесі запліднення; <...>. Словник обіймає нормативну загальнонаукову та широковживану біологічну термінологію, зафіксовану в науковій, науково-популярній, навчальній та інформативно-реферативній літературі, енциклопедичних, загальномовних і спеціальних словниках і довідниках. У Словнику відсутні вузькоспеціальні, застарілі терміни та новотвори, не апробовані в колі фахівців» (Потоцький 182).

Критик проводить експертизування й нелексикографічних параметрів словника, його невербальних характеристик, звертаючи увагу на оформлення зовнішнього вигляду: «Ця оригінальна лексикографічна праця видрукувана за технологіями сучасної поліграфії, друк і папір офсетні. Гарний шрифт» (Потоцький 182). Рецензент-фахівець, як бачимо, високо оцінює словник і його зовнішній вигляд, без указівки на прогалини видання. Критик висловлює побажання, що стосуються збільшення накладу праці й розширення колективу укладачів: «Хочеться побажати 
колективу укладачів докласти усіх зусиль до видання більшого накладу, він заслуговує 10-тисячного. У подальшому до складу колективу укладачів залучити фахівців окремих галузей біології» (Потоцький 182). Отже, у рецензіях фахівців оцінка словника займає декілька рядків на початку або абзац - у їхньому кінці.

Рецензія мовознавця / термінографа - це значна за обсягом критична стаття (понад 2 с.) 3 глибоким експертизуванням структури термінографічної праці та рясними прикладами аналізу. Зокрема, І. Кочан, д-р філол. наук, професор, досвідчений і знаний термінолог та термінограф підкреслює вагомість розглядуваного словника: «3 упевненістю можна констатувати, що така праця не має аналогів у вітчизняній термінографії» (86). Критик робить екскурс в історію спеціального словникарства, підкреслює складні умови створення словників з біології і надважливість виходу у світ цієї термінографічної праці. І. Кочан ретельно вивчає реєстр словника, принцип репрезентування реєстрових одиниць, наведену граматичну характеристику до іменників і прикметників, а також синоніми, установлює наявність в описаній термінології чималої кількості чужомовних термінів та елементів, «що свідчить про спільний міжнародний термінофонд національної терміносистеми» (87). При цьому авторка наголошує: «<..> слід віддати належне укладачам за надання переваги національним термінам: буряк, вічко, живокіст, лялечка, обніжки тощо» (Кочан 88). Експерт відстежує здатність біологічних термінів утворювати численні терміносполучення, що наведені в терміностатті: «Найбільшими за обсягом є статті з реєстровими словами рослина (94 терміни-словосполучення), орган (30 словосполучень), організм (29 словосполучень)» (Кочан 87).

Цінною $є$ порада зазначеної вище дослідниці щодо засад добирання термінів до реєстру словника, зокрема: «Однак нам видається, що серед реєстрових слів є такі, які можна б було замінити іншими назвами. Так, замість слова пучок сьогодні пропонують уживати жмут, щука - щупак, а розоцвіті - рожевоцвіті» (Кочан 88). Отже, рецензент-термінограф слушно й переконливо показує користь спеціальної праці для науки та її переваги, його оцінка словника $є$ аргументованою й глибокою.

1.2. Колективна рецензія - це рецензія, написана у співавторстві, тобто це спільний експертний висновок стосовно якості словника кількома критиками:

а) рецензія представників одного фаху - це рецензія на словник крізь призму знань спеціалістів однієї галузі знань (напр., мовознавців (Веклинець, i Разумейко), галузевих фахівців (Ніколайчук, i Вайда));

б) рецензія представників різного фаху - це критична стаття (обсягом понад 2 с.), у якій експерти комплексно розглядають словник щодо відповідності принципу побудови праць такого типу й точності лексикографічного опису термінів тощо. 
Наприклад, Ю. Колупаєв, д-р біол. наук, професор, і Р. Трифонов, канд. філол. наук, доцент, підготували розлогу й змістовну рецензію на зазначений вище «Словник української біологічної термінології». Критики насамперед відзначають важливість виходу у світ цієї праці, зауважуючи, що «словник <..> став першою масштабною вітчизняною лексикографічною працею новітнього часу, що охоплює найуживанішу термінологію біологічних та суміжних наук», «має всі підстави зайняти місце наріжної, фундаментальної праці <..>» (Колупаєв, і Трифонов 101). Експерти підкреслюють переваги праці, зокрема: «Системне лексикографічне опрацювання біологічної термінології в ньому здійснене широко і фахово, сучасно й поліаспектно. <...> Цінним $\epsilon$ те, що праця вдало поєднує в собі два типи словників: тлумачний (дефінітивний) і тримовний перекладний» (Колупаєв, і Трифонов 101).

Проаналізувавши структуру терміностатей, критики доходять висновку, що словник є зручним у користуванні, однак «варто було б у словникових статтях подавати першим англійський відповідник українського терміна, оскільки саме англійська $\epsilon$ провідною мовою світової науки <...> (Колупаєв, і Трифонов 101). Однак рецензенти вказують і на відсутність у виданні багатьох нових термінів, що відображають цілі напрями розглядуваної науки, напр.: «якщо у словнику $\epsilon$ терміни геноміка, геном і навіть епігеном, то чому відсутні протеом і протеоміка? Залишилися практично не відображеними й терміни з такого сучасного актуального напряму цитофізіології, <...>. Замало уваги приділено біологічно активним речовинам (наприклад, немає терміна оксид азоту, хоча є нітрат, відсутні відомості про нові групи фітогормонів брасиностероїди, жасмонати, саліцилати, системін тощо) (Колупаєв, і Трифонов 102).

Експерти відстежують, що в словнику репрезентовано і терміни, і номенклатурні назви, у зв'язку з чим зауважують несистематичність і різноспрямованість «тлумачень, які подано до номенклатури» (Колупаєв, і Трифонов 102).

У підсумку співавтори рецензії оцінюють словник позитивно, наголошуючи, що його вихід у світ $\epsilon$ вагомою подією і для вітчизняної біології, і для української лексикографії. «Науковці-біологи здебільшого звертатимуться до словника задля уточнення чи перекладу термінів, <...> академічний словник повністю виконує функцію нормативної праці» (Колупаєв, і Трифонов 103). Рецензенти висловлюють сподівання, що словник, «випущений накладом усього 1000 примірників, надалі матиме наступні видання, а також електронну версію» (Колупаєв, і Трифонов 103). Це засвідчує високу оцінку словника означеними науковцями.

Виділені й розглянуті типи рецензій за фахом і кількістю рецензентів, як бачимо, різняться обсягом, глибиною аналізування й ступенем аргументування переваг чи недоліків словника. 


\section{2. Рецензії за ознакою 'тип журналу, у якому вміщено рецензію'.} Головна аудиторія читачів і користувачів словникової рецензії - це наукове співтовариство, фахівці різних галузей, насамперед термінологи, термінографи та інші небайдужі до фахових словників учені. Науковий журнал $\epsilon$ основним джерелом інформування про 'свіжі' результати досягнень науки й техніки. Рецензії на термінографічні праці розміщують у наукових журналах академічного або неакадемічного (науковопопулярного) рівнів, за носієм інформації - у видрукуваних на папері, тобто паперових, та електронних журналах.

Наукові академічні журнали - це часописи, що $\epsilon$ продуктом академії наук або провідних наукових установ, інститутів, закладів вищої освіти, у яких публікують роботи з певних академічних та галузевих наук (напр., в Україні це «Мовознавство», «Термінологічний вісник», «Українська мова», «Вісник Академії наук правових наук України», «Вісник НАН України», «Український ботанічний журнал» тощо). Усі інші журнали розглядаємо як журнали неакадемічного (науково-популярного) рівня.

Останнім часом деякі часописи вводять у свою структуру обов'язкові розділи, що мають такі назви: «Рецензії», «Рецензії та огляди», «Книжковий огляд» («Book reviews», «Reviews»). У тих же виданнях, у яких вони вже були задекларовані, їх розширюють. Зазначмо, що в наявних журнальних рубриках не уточнюють тип викладених рецензій, що змушує кожного читача ідентифікувати їх самостійно і свідчить про нагальну потребу розроблення їхньої типології.

Організація рецензійних розділів засвідчує дотримання стратегії журнального менеджменту й текстів такого типу. Наявність сучасних електронних наукових журналів, у яких репрезентовано рецензії на термінологічні словники (напр., у виданні «Принт плюс» розміщена рецензія Е. Лазаренка, О. Мельникова на «Український тлумачний словник видавничо-поліграфічної справи»; у «CERAMO DEFECT» - «Рецензія: Образотворче мистецтво: Енциклопедичний ілюстрований словникдовідник») певною мірою модифікує не лише систему наукової комунікації загалом, а й інститут рецензування зокрема. Як зазначає український дослідник рецензій, спроектованих на статті, М.Женченко, новою прогресивною закордонною моделлю наукового рецензування $\epsilon$ відкрите онлайнове критикування наукової періодики, що передбачає безперешкодний доступ до створеного на сайті електронного журналу рецензій (169). Російський дослідник Б. Степанов стосовно електронних рецензій зауважує: «Електронний формат: 1) створює умови для швидкого реагування на видання, що з'являються, та обліку тих видань, які виявляються на периферії рецензійного горизонту традиційних видань; 2) знімає обмеження і за обсягом публікованих рецензій, і стосовно їхнього наповнення: публікація рецензій з легкістю може супроводжуватися картинками, відеороликами і т. д.; 3) спрощує систему публікації текстів, робить їх більш доступними, створює можливості для більш 
неформального обговорення тих питань, які висвітлюються в рецензіях; 4) адаптує корпус рецензій за допомогою використання електронних підписок і розсилань на запити аудиторії, що диференціюється <...> (переклад автора. - Т. П.) (87-88).

Означені переваги рецензій в електронних виданнях, насамперед їхня доступність, можуть створювати загрозу для якісної оцінки спеціальних словників, а отже, важлива роль рецензії в поліпшенні методології репрезентування термінологічної галузі як системи може бути спростована. На основі викладеного, зважаючи на наявність нових форм і засобів організації оцінювання термінографічних праць, можна однозначно стверджувати, що критики повинні би дотримуватися єдиних вимог рецензування словників на сторінках наукових паперових журналів та електронних видань задля формування національного (або міжнародного) інституту рецензування термінологічних словників.

Отже, розглянуті жанрові типи постпублікаційних рецензій на термінологічні словники за ознаками 'кількість авторів рецензії' та 'тип журналу, у якому вміщено рецензію’ вирізняються наявністю численних неоднорідних їхніх підтипів (див. таблиця 1).

Таблиця 1

Жанрові типи й підтипи рецензій на термінологічні словники за ознаками

'кількість авторів рецензіі', 'тип журналу, у якому вміщено рецензію'

\begin{tabular}{|c|c|c|c|c|}
\hline $\begin{array}{c}\text { Пор. } \\
\text { № }\end{array}$ & $\begin{array}{c}\text { Ознаки } \\
\text { рецензій }\end{array}$ & Типи рецензій & \multicolumn{2}{|c|}{ Підтипи рецензій } \\
\hline \multirow[t]{3}{*}{1} & \multirow{3}{*}{$\begin{array}{l}\text { Кількість } \\
\text { авторів } \\
\text { рецензії }\end{array}$} & & \multicolumn{2}{|c|}{ за фахом експертів } \\
\hline & & одноосібні & $\begin{array}{l}\text { рецензії } \\
\text { галузевих } \\
\text { фахівців }\end{array}$ & $\begin{array}{l}\text { рецензї̈ } \\
\text { мовознавців / } \\
\text { термінографів }\end{array}$ \\
\hline & & колективні & $\begin{array}{l}\text { рецензія } \\
\text { представників } \\
\text { одного фаху }\end{array}$ & $\begin{array}{l}\text { рецензія } \\
\text { представників } \\
\text { різного фаху }\end{array}$ \\
\hline \multirow[t]{4}{*}{2} & \multirow{4}{*}{$\begin{array}{l}\text { Тип журналу, } \\
\text { у якому } \\
\text { вміщено } \\
\text { рецензію }\end{array}$} & рецензії в наукових & \multicolumn{2}{|c|}{ за напрямом журналу } \\
\hline & & академічних журналах & $\begin{array}{l}\text { у } \\
\text { лінгвістичних }\end{array}$ & у галузевих \\
\hline & & рецензії в журналах & \multicolumn{2}{|c|}{ за носієм інформації } \\
\hline & & $\begin{array}{l}\text { неакадемічного } \\
\text { (науково-популярного) } \\
\text { рівня }\end{array}$ & електронні & паперові \\
\hline
\end{tabular}

Висновки та перспективи досліджень. Запропонована багатоаспектна жанрова типологія $\epsilon$ універсальною та відкритою системою. Із часом можуть актуалізуватися нові параметри (ознаки), відповідно, можуть з'явитися нові типи й підтипи рецензій. Типологійна 
система рецензій на термінологічні словники вирізняється численністю й неоднорідністю їхніх типів та підтипів.

За ознакою 'кількість авторів' існують такі типи й підтипи рецензій: 1) одноосібні (за фахом експертів - рецензії галузевих фахівців і рецензії мовознавців / термінографів; 2) колективні (за фахом експертів - рецензії представників одного фаху й рецензії представників різного фаху). Виділені типи рецензій за фахом і кількістю рецензентів різняться обсягом, глибиною аналізування й ступенем аргументування переваг чи недоліків словника.

За ознакою 'тип журналу, у якому вміщено рецензію' виокремлено 1) рецензії в наукових академічних журналах (за напрямом журналу у лінгвістичних та в галузевих), 2) рещензії в журналах неакадемічного (науково-популярного) рівня (за носієм інформації - електронні й паперові). Існування значної кількості жанрових різновидів та сучасних джерел репрезентування рецензії засвідчує її запотребованість і важливу роль як інструмента підвищення якості національної термінографічної продукції.

Перспективу досліджень проблематики жанрового типологізування рецензій на термінологічні словники пов'язуємо з детальним вивченням усіх типів рецензій (та їхніх підтипів), що формують всеохопну багатоакспектну їхню класифікацію, 3 метою створення інваріантного типу рецензії на спеціальне видання.

\section{Список використаної літератури}

Веклинець, Леся, Разумейко, Марія. «Новий термінологічний словник». Культура народов Причерноморья, № 36, 2002, с. 197-8.

Гуманенко, Олександра. «Особливості типологічної характеристики рецензій на наукові твори». Наукові записки, № 3, 2011, с. 119-126.

Женченко, Марина. «Нова модель рецензування наукових публікацій у цифровому середовищі». Держава та регіони. Серія: Соціальні комунікації, № 1 (25), 2016, с. 169-72.

Загнітко, Аанатолій. Словник сучасної лінгвістики: поняття і терміни. У 4 т. Т. 1. Донецьк, 2012.

Колупаєв, Юрій, і Трифонов, Роман. «Словник української біологічної термінології. Укладачі: Д. М. Гродзинський, Л. О. Симоненко, М. П. Годована, С. В. Овсейчик, Л.В. Туровська, Н. О. Яценко, Л. М. Василькова. К.: КММ, 2012. 744 с.». Вісник Харківського національного аграрного університету. Серія Біологія, вип. 2 (32), 2014, c. 101-3.

Космеда, Тетяна. «Збагачення української лінгвістичної термінологічної лексикографії. Рец. на словник: Загнітко А. П. Словник сучасної лінгвістики: поняття і терміни (Текст)/ Анатолій Панасович Загнітко: у 4 т. - Донецьк: ДонНУ, 2012». Лінгвістичні студії, вип. 28, 2014, с. 194-8.

Кочан, Ірина. «Велика подія в біологічній термінографії. Рецензія на “Словник української біологічної термінології”. К.: КММ, 2012. - 744 с.». Вісник Національної академії наук України, № 10, 2003, с. 86-8.

Лассан, Элеонора. «Рецензия как жанр и как речевой акт». Лингвистика речи. Медиастилистика. Москва, 2012, с. 190-206.

Левчук, Ірина. «Комунікативні ознаки рецензійного дискурсу». Studia Ukrainica Posnaniensia, zesz. I, 2013, c. 99-107. 
Літературознавчий словник-довідник, за ред. Р. Т. Гром’яка, Ю. І. Коваліва та ін. Київ, 1997.

Мех, Наталія. «Жанросфера сучасної української наукової комунікації». Мова $i$ міжкультурна комунікація, вип. 1, 2017, с. 64-73.

Ніколайчук, Віталій, Вайда, Петро. «Рецензія на “Словник найуживаніших термінів 3 екології, біотехнології і біоенергетики"». Науковий вісник Ужгородського університету. Серія Біологія, вип. 28, 2010, с. 161.

Петрова, Тетяна. «Рецензія на термінологічний словник: експертиза, професійний діалог і наукова дискусія». Лінгвістичні студії Linguistic Studies, вип. 38, 2019, с. 84-88, doi: 10.31558/1815-3070.2019.38.13.

Петрова, Тетяна. «Рецензія на термінологічний словник як жанр критичного субдискурсу». Наукові праці Кам'янець-Подільського національного університету імені Івана Огієнка: Філологічні науки, вип. 50, 2019, с. 133-9.

Петрова, Тетяна. «Українська термінографічна критика: від витоків до сучасності». Науковий вісник Національного університету біоресурсів і природокористування України. Серія Філологічні науки, № 292, 2018, с. 208-17.

Потоцький, Микола. «Словник української біологічної термінології - неординарна подія в українській лексикографії». Термінологічний вісник, вип. 2 (2), 2013, c. $181-182$.

Словник української біологічної термінології. Київ, 2012.

Степанов, Борис. “"Кризис жанра”: книжные рецензии в перспективе исследований научной коммуникации». Laboratorium, 8 (1), 2016, с. 82-106.

Чернышова, Маргарита. «Параметры лексикографической критики». Слово и словарь, № 12, 2011, c. 7-10.

Щербин, Владимир. «Вклад О. Н. Трубачева в развитие научной критики словарей». Вопросы языкознания, № 5, 2007, с. 3-21.

Яценко, Ніна. «Жанрово-стильова специфіка наукової рецензії». Українська мова, № 1 (61), 2017, c. 92-101.

Bergenholtz, Henning, Gouws, H. Rufus. "On the Metalexicographic Genre of Dictionary Reviews, with Specific Reference to LexicoNordica and Lexikos". Lexikos, no 26, 2016, pp. 60-81, doi: 10.5788/26-1-1358.

\section{References}

Veklynets, Lesia, Razumeiko, Mariia. "Novyi terminolohichnyi slovnyk". Kultura Narodov Prichernomoria, no. 36, 2002, pp. 197-8.

Humanenko, Oleksandra. "Features of Tipologichnoy Description of Reviews are on Scientific Works". Scientific Papers, no. 3, 2011, pp. 119-26.

Zhenchenko, Maryna. "The New Model of Scientific Publications Peer Review in the Digital Environment". Derzhava ta rehiony. Seriya: Sotsialni komunikatsiyi, iss. 1 (25), 2016, pp. 169-72.

Zahnitko, Aanatolii. Slovnyk suchasnoi linhvistyky: poniattia i terminy. 4 vols. Vol. 1. Donetsk, 2012.

Kolupaiev, Yurii, and Tryfonov, Roman. "Slovnyk ukrainskoi biolohichnoi terminolohii. Ukladachi: D. M. Hrodzynskyi, L. O. Symonenko, M. P. Hodovana, S. V. Ovseichyk, L.V. Turovska, N. O. Yatsenko, L. M. Vasylkova. K.: KMM, 2012. 744 s.”. The Bulletin of Kharkiv Nayional Agrarian University. Series Biology, iss. 2 (32), 2014, pp 101-3.

Kosmeda, Tetiana. "Zbahachennia ukrainskoi linhvistychnoi terminolohichnoi leksykohrafii. Rets. na slovnyk: Zahnitko A. P. Slovnyk suchasnoi linhvistyky: poniattia i terminy (Tekst)/ Anatolii Panasovych Zahnitko: u 4 t. - Donetsk: DonNU, 2012". Linguistic Studies, iss. 28, 2014, pp. 194-8. 
Kochan, Iryna. "Velyka podiia v biolohichnii terminohrafii. Retsenziia na "Slovnyk ukrainskoi biolohichnoi terminolohii". K.: KMM, 2012. - 744 s.”. Herald of National Academy of Sciences of Ukraine, no. 10, 2003, pp. 86-8.

Lassan, Эleonora. "Retsenzyia kak zhanr y kak rechevoi akt". Lynhvystyka rechy. Medyastylystyka. Moskva, 2012, pp. 190-206.

Levchuk, Iryna. "Komunikatyvni oznaky retsenziinoho dyskursu". Studia Ukrainica Posnaniensia, zesz. I, 2013, pp. 99-107.

Literaturoznavchyi slovnyk-dovidnyk, edited by R. T. Hromiak, Yu. I. Kovaliv and all. Kyiv, 1997.

Mekh, Nataliia. «Zhanrosfera suchasnoi ukrainskoi naukovoi komunikatsii». Mova $i$ mizhkulturna komunikatsiia, iss. 1, 2017, pp. 64-73.

Nikolaichuk, Vitalii, Vaida, Petro. "Retsenziia na "Slovnyk naiuzhyvanishykh terminiv z ekolohii, biotekhnolohii i bioenerhetyky"'”. Scientific Bulletin of the Uzhhorod University. Series Biology, iss. 28, 2010, p. 161.

Petrova, Tetiana. "Review of a terminological dictionary: examination, professional dialogue and scientific discussion". Linguistic Studies, iss.38, 2019, pp.84-88, doi: 10.31558/1815-3070.2019.38.13.

Petrova, Tetiana. "The review of a terminology dictionary as a critical sub-discourse genre". Naukovi pratsi Kamianets-Podilskoho natsionalnoho universytetu imeni Ivana Ohiienka: Filolohichni nauky, iss. 50, 2019, pp. 133-9.

Petrova, Tetiana. "Ukrainian termonografical criticism: from origin to modern times". Naukovyi visnyk Natsionalnoho universytetu bioresursiv i pryrodokorystuvannia Ukrainy. Seriia Filolohichni nauky, no. 292, 2018, pp. 208-17.

Pototskyi, Mykola. "Slovnyk ukrainskoi biolohichnoi terminolohii - neordynarna podiia v ukrainskii leksykohrafii". Terminolohichnyi visnyk, no. 2, 2013, pp. 181-182.

Slovnyk ukrainskoi biolohichnoi terminolohii. Kyiv, 2012.

Stepanov, Boris. "Crisis of the Genre: Book Reviews in Studies of Scholarly Communication". Laboratorium, no. 8 (1), 2016, pp. 82-106.

Chernyshova, Margarita. "Parametry leksikograficheskoj kritiki". Vocabulum et vocabularium, no. 12, 2011, pp. 7-10.

Shherbin, Vladimir. "Vklad 0. N. Trubacheva v razvitie nauchnoj kritiki slovarej". Topics in the Study of Language, no. 5, 2007, pp. 3-21.

Yatsenko, Nina. "Scientific Review: Genre and Stilistic Specificity". Ukrainska mova, no. 1, 2017, pp. 92-101.

Bergenholtz, Henning, Gouws, H. Rufus. "On the Metalexicographic Genre of Dictionary Reviews, with Specific Reference to LexicoNordica and Lexikos". Lexikos, no. 26, 2016, pp. 60-81, doi: 10.5788/26-1-1358. 